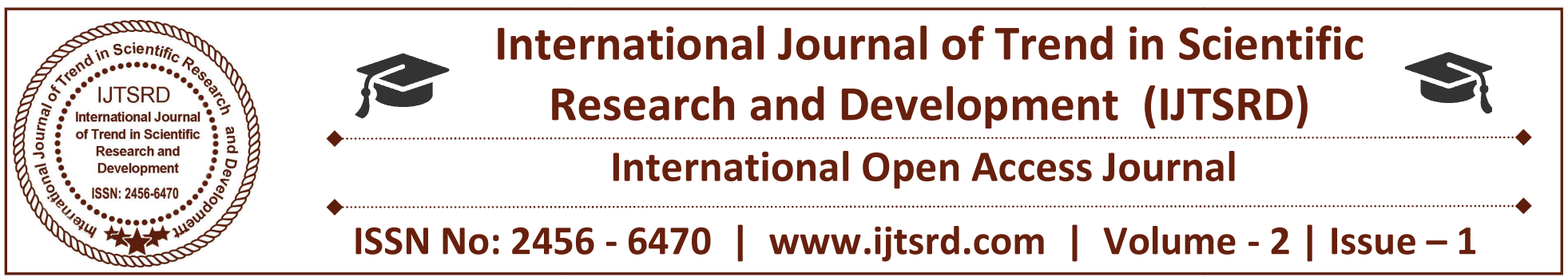

\title{
Consumers Awareness, Attitude and Preference towards Patanjali Retail Products
}

\author{
Neeta Rani \\ Commerce, Research Scholar in IMSAR, \\ MDU, Rohtak, Haryana, India
}

\section{ABSTRACT}

The Indian herbal market is flooded with many wellknown and recognized herbal brands. Patanjali Ayurved is an initiative to supply unadulterated Ayurvedic products to the customers and for generating profitable employment for the weak and poor section of the society. In this paper main stress has been given on the consumer awareness, attitude and preference towards 'Patanjali' retail products. For this purpose data was collected through structured questionnaire both closed- ended and open- ended. A sample of 1000 respondenents was collected through questionnaire. Data analyses have been done with the help of SPSS. 20. The study is limited to Rohtak, Sonepat, Panipat and Jhajjar districts in Haryana state.

Keywords: Consumers awareness, consumer's attitude, consumer's preferences, Patanjali retail products

\section{1) INTRODUCTION}

A WHO (World Health Organization) study indicates that about 80 percent of world population depends on herbal products for their health care instead of prevailing medicines primarily because of harmful effects and high cost of contemporary medicine. The worldwide herbal market goods are around $\$ 6.2$ billion and estimated to reach $\$ 5$ trillion by the year 2050.

Indian herbal exports valued at about INR (Indian National Rupee) 874 crores (1crore $=10$ million) in 2001-02 constitute about 73 percent in the form of crude drugs and extracts and 27 percent as finished products. The Indian herbal market is registering an amazing growth and is likely to reach INR 14,500 crore and exports to INR 9,000 crore with a CAGR of 20 and 25 percent respectively, according to Associated Chambers of Commerce and Industry of India (Assocham).Government of India established AYUSH re-naming ISM\&H (Department of Indian System of Medicine and Homeopathy) in November 2003 to promoted herbal cure.

Currently the demand for traditional Indian herbal products has increased mainly in India and abroad. Fast Moving Healthcare Goods (FMHG) in India worldwide known as Nutraceutical, (defined as, ingredients with human health benefits ahead of basic nutrition) industry is expected to grow by 20 percent to USD 6.1 billion by $2019-2020$ due to increasing awareness about health and fitness and changing living standard. However, nutritional supplements, herbal and nutritional supplements will form the greatest opportunity areas for Nutraceutical processing, motivated by increasing demand from an developing consumer base. Some of the major players in the Indian herbal market are Patanjali, Dabur, Himalaya, Vicco, Emami and others.

\section{Patanjali Ayurved Limited}

Patanjali Ayurved Limited is an Indian FMCG enterprise located in the industrial area of Haridwar, the company produces mineral and herbal products. According to CLSA and HSBC, Patanjali is the fastest growing fast-moving consumer company in India. It is valued at 13000 crore (US\$1.9 billion) and some estimate revenues of 5000 crore (US\$740 million) for the fiscal 2016-17. 


\section{History}

Acharya Balkrishna developed Patanjali Ayurved Limited in 2006 along with Baba Ramdev with the objective of establishing science of Ayurveda in accordance and coordinating with the latest technology and ancient.

\section{Revenues}

Patanjali Ayurveda's annual sales for the year 2014-15 increased to 2500 crore (US\$370 million) as compared to previous sales of 1200 crore (US $\$ 180$ million) (2013-14),850 crore (US\$130 million) (2012-13) and 450 crore (US\$67 million) (2011-12). Future Group which has tied up with Patanjali sells about 30 crore (US\$4.5 million) worth of Patanjali products every month.

\section{Production}

Patanjali Food and Herbal Park at Haridwar is the main production facility operated by Patanjali Ayurved. The company plans to establish further units in India and in Nepal.

In 2016, the Patanjali Food and Herbal Park was given a full-time security cover of 35 armed Central Industrial Security Force (CISF) commandos. The park will be the eighth private institute in India to be guarded by CISF paramilitary forces. Baba Ramdev is himself a "Z" category protectee of central paramilitary forces

\section{Products}

Patanjali Ayurved manufactured products in the categories of personal care and food .The Company provides 444 products including 45 types of cosmetic products and $\mathbf{3 0}$ types of food products. According to Patanjali, all the products provided by Patanjali are made from Ayurveda and natural ingredients. Patanjali products have reasonable prices than alternatives in the market due to lowest production and marketing costs. Patanjali has also started to manufacture beauty and baby products. Patanjali Ayurvedic producing division has over 300 medicines for treating a range of ailments and body conditions, from common cold to chronic paralysis.Patanjali started to manufacture instant noodles on 15 November 2015.Food Safety and Standards Authority of India slapped a notice on the company as neither Patanjali nor Aayush, which are the two brand names under which Patanjali got licenses, have got any approval for manufacturing instant noodles.

\section{Sales and distribution}

Patanjali Ayurved provide products through nearly 4000 retail outlets as of 2015.Patanjali also sells its products online and is trying to open outlets at railway stations and airports.

\section{2) REVIEW OF LITERATURE:}

1. Somvanshi (2016) in her article, "Patanjali's success may lead to a FMCG rejig" analyzed that Patanjali has emerged as a serious threat for mainstream FMCG companies - especially for the likes of Colgate Palmolive, Dabur and Emami. Brokerages such as Credit Suisse have downgraded Colgate Palmolive to neutral as Patanjali toothpaste eats into the market leader's share. There is a great likelihood of more earnings downgrades to follow as Patanjali products continue to garner market share in packaged foods and personal care products.

2. Anand et. al, (2016) in their article, "Baba Ramdev alleges adulteration of Patanjali products by FMCG companies" studied that Yoga guru Ramdev has gone on the offensive against global consumer goods makers as his Patanjali brand fights for market share against the top-selling products of Hindustan Unilever, Nestle and Colgate-Palmolive. Ramdev accused them on Monday of conspiring against Patanjali by getting fake and adulterated products tested in laboratories for irregular results. They were doing this because they fear his firm is winning over customers, he said.

3. Ghosal (2016) in his article, "Solvent extractors to approach food, advertising regulators against Patanjali advertisement" analyzed that: The Solvent Extractors' Association of India (SEA) has said it will ask the food and advertising regulators to direct yoga guru Baba Ramdev's Patanjali Ayurved to withdraw its advertisement on kachhi ghani mustard oil, which it said is misleading. In a press release issued on April 21, SEA president Pravin Lunkad said, "Our association always supports the domestic producers of edible oils of any type. However, we do not.

4. Somvanshi (2016) in her article, "Six lessons that Patanjali teaches India's FMCG sector" analyzed that a decade ago it was modern trade which changed the way Indians shopped. Then came e-commerce and 
online shopping. And this time around it is Patanjali Ayurveda - the latest force to disrupt the branded consumer goods sector. Its raging popularity and strong brand resonance have some incisive lessons for the Indian fast moving consumer goods (FMCG) sector. Brand Premium - What's that? A brand doesn't have to charge a premium to resonate better.

5. Vyas (2016) in his article, "After Patanjali, existing FMCG players may face challenge from Sri Sri Ravi Shankar's Sri..." studied that The FMCG sector may be in for some more disruption as analysts believe that after Baba Ramdev's Patanjali shook up the space, Sri Sri Ravi Shankar's Sri Sri Ayurveda (SSA) products will now make the going tougher for the existing consumer players. A recent report by Edelweiss Securities says that while Sri Sri Ayurveda has a long way to go before it can emulate Patanjali's success; the path will nevertheless be easier.

\section{3) RESEARCH METHODOLOGY:}

The research design is descriptive and exploratory in nature, because the aim is to describe about Patanjali and herbal marketing and relative important concepts and to find out some implications and suggestions. Primary data was collected through questionnaire and secondary data was collected through articles, journals, magazines and online sources. A sample of 1000 respondents was collected from Rohtak, Sonepat, Panipat and Jhajjar districts.

Objective of the study: To study the consumer awareness, attitude and preference for 'Patanjali' retail products with respect to its various competing brands.

\section{4) DATA ANALYSES INTERPRETATIONS:}

This chapter deals with the following points:

\section{1) DESCRIPTIVE ANALYSIS:}

The background information about the 1000 respondents included in the sample is presented below:

1) Location wise distribution: Understanding about the location of respondents helps to know the effect of Patanjali brand in different areas and the place where the individual is living in has a huge influence of that region on his behavior. Hence this information was captured for this study.

AND
Table 4.1 shows the distribution of respondents on location basis.

\section{TABLE4.1}

\begin{tabular}{|c|c|c|}
\hline \multicolumn{3}{|c|}{$\begin{array}{l}\text { LOCATION-WISE DISTRIBUTION OF SAMPLE } \\
\text { RESPONDENTS }\end{array}$} \\
\hline Location & Frequency & Percent \\
\hline PANIPAT & 250 & 25.0 \\
\hline JHAJJAR & 250 & 25.0 \\
\hline ROHTAK & 250 & 25.0 \\
\hline SONEPAT & 250 & 25.0 \\
\hline Total & 1000 & 100.0 \\
\hline
\end{tabular}

2) Sex wise distribution: The role of gender towards purchasing products is considered important, because the influencing factors for men and women might be different Table 4.2 shows the frequency distribution of respondents on sex basis.

TABLE 4.2

\begin{tabular}{|c|c|c|}
\hline $\begin{array}{l}\text { SEX-WISE } \\
\text { RESPONDENT }\end{array}$ & $\begin{array}{l}\text { DISTRIBUTION } \\
\text { S }\end{array}$ & SAMPLE \\
\hline Category & Frequency & Percent \\
\hline FEMALE & 696 & 69.6 \\
\hline MALE & 304 & 30.4 \\
\hline Total & 1000 & 100.0 \\
\hline
\end{tabular}

3) Age wise distribution: Experience makes a person perfect. An experienced person can develop his own ideas and perception and acts accordingly. This is the reason that the age factor kept in mind for making suitable marketing strategies. The respondents were divided into four age categories. Table 4.3 shows the frequencydistribution of respondents' age wise.

TABLE 4.3

\begin{tabular}{|c|c|c|}
\hline \multicolumn{2}{|c|}{$\begin{array}{l}\text { AGE-WISE DISTRIBUTION } \\
\text { RESPONDENTS }\end{array}$} & SAMPLE \\
\hline Category (in years) & Frequency & Percent \\
\hline BELOW 20 & 538 & 53.8 \\
\hline $20-30$ & 322 & 32.2 \\
\hline $30-40$ & 39 & 3.9 \\
\hline $\begin{array}{l}40 \quad \text { AND } \\
\text { ABOVE }\end{array}$ & 101 & 10.1 \\
\hline Total & 1000 & 100.0 \\
\hline
\end{tabular}

4) Education /Qualification wise distribution: Understanding about education helps the marketers to know the understanding level of the respondents of different qualifications which helps 
International Journal of Trend in Scientific Research and Development (IJTSRD) ISSN: 2456-6470

in developing marketing strategies according to their understanding basis and aim was to check if qualification. Table 4.4 shows the education wise the influencing factors differed based with their frequency distribution of the respondents.

\begin{tabular}{|l|c|c|}
\hline \multicolumn{3}{|c|}{ TABLE4.4 } \\
EDUCATION-WISE DISTRIBUTION OF SAMPLE RESPONDENTS \\
\hline \multicolumn{1}{|c|}{ Category } & Frequency & Percent \\
\hline UNEDCATED & 39 & 3.9 \\
\hline BELOW 10TH & 32 & 3.2 \\
\hline UP TO 10TH & 15 & 1.5 \\
\hline UP TO 12TH & 554 & 55.4 \\
\hline GRADUATE & 249 & 24.9 \\
\hline POST GRADUATE & 98 & 9.8 \\
\hline AND ABOVE & 13 & 1.3 \\
\hline Total & $\mathbf{1 0 0 0}$ & $\mathbf{1 0 0 . 0}$ \\
\hline
\end{tabular}

5) Occupation wise distribution: A person's occupation plays an important role in influencing his/her buying decision. Keeping this into consideration, an attempt was made to classify the respondents on the basis of their working status. Table 4.5 shows the working status wise distribution of the respondents.

\begin{tabular}{|l|c|c|}
\hline \multicolumn{3}{|c|}{ TABLE 4.5: } \\
WORKING STATUS WISE DISTRIBUTION OF SAMPLE RESPONDENTS \\
\hline \multicolumn{1}{|c|}{ Category } & Frequency & Percent \\
\hline NOT WORKING & 12 & 1.2 \\
\hline FARMING & 61 & 6.1 \\
\hline STUDENT & 792 & 79.2 \\
\hline GOVT.JOB & 54 & 5.4 \\
\hline PRIVATE JOB & 74 & 7.4 \\
\hline BUSINESS & 7 & .7 \\
\hline Total & 1000 & 100.0 \\
\hline
\end{tabular}

5) Average monthly income wise distribution: Economic ability must be combined with willingness to purchase. Therefore marketers decide the suitable marketing mix elements to be adopted specially related to pricing of the product. Table 4.6 shows the frequency distribution of respondents on the basis of the family average monthly income.

\begin{tabular}{|c|c|c|}
\hline \multirow{2}{*}{\multicolumn{3}{|c|}{$\begin{array}{l}\text { TABLE 4.6: } \\
\text { AVERAGE MONTHLY INCOME WISE DISTRIBUTION OF SAMPLE RESPONDENTS }\end{array}$}} \\
\hline & & \\
\hline LESS THAN 5000 & 48 & 4.8 \\
\hline $5000-10000$ & 590 & 59.0 \\
\hline $10000-20000$ & 217 & 21.7 \\
\hline $20000-30000$ & 77 & 7.7 \\
\hline 30000 AND ABOVE & 68 & 6.8 \\
\hline Total & 1000 & 100.0 \\
\hline
\end{tabular}


International Journal of Trend in Scientific Research and Development (IJTSRD) ISSN: 2456-6470

4.2 CONSUMER AWARENESS, ATTITUDE out consumer awareness with respect to Patanjali AND PREFERENCE FOR PATANGALI products by four elements:

PRODUCTS: EMPIRICAL ANALYSES

This aim is further divides into the following parts:

4.2.1) Consumers awareness for Patanjali retail products: In marketing consumers awareness means that consumers are aware of products or services, its characteristics and the other marketing P's like price,

4.2.1).1) Extent of familiarity with regards to Patanjali retail products: For this purpose the researcher has filled a question through 1000 respondents that "To what extent they are familiar with the 'Patanjali retail products'?". Table 4.7 shows the response of 1000 respondents. place, promotion etc. The researcher has tried to find

\begin{tabular}{|l|l|l|l|}
\hline $\begin{array}{l}\text { TABLE4.7 } \\
\text { Extent of familiarity }\end{array}$ & \\
\hline Category & Frequency & Percent & Cumulative Percent \\
\hline Very well & 855 & 85.5 & 85.5 \\
\hline Heard of & 137 & 13.7 & 99.2 \\
\hline Don't know & 8 & .8 & 100 \\
\hline Total & 1000 & 100.0 & \\
\hline
\end{tabular}

It is cleared from the table that 855 respondents out of 1000 or $85.5 \%$ are familiar with Patanjali brand and also they have used Patanjali products, 137 or $13.7 \%$ respondents have only heard about Patanjali but they have never used it and 8 or $0.8 \%$ respondents said that they don't know about Patanjali products.

4.2.1).2 Their knowledge about Patanjali for the $1^{\text {st }}$ time: For this purpose the researcher has asked a question from the buyers of the Patanjali products that 'from where they came to know about Patanjali for the $1^{\text {st }}$ time'. Table 4.8 shows the response of 855 buyers of the Patanjali products.

\begin{tabular}{|c|c|c|c|c|}
\hline \multicolumn{5}{|c|}{\begin{tabular}{|l|} 
TABLE 4.8 \\
Knowledge about Patanjali products for the $1^{\text {st }}$ time
\end{tabular}} \\
\hline \multicolumn{2}{|c|}{ Category } & Frequency & Percent & Valid Percent \\
\hline & TV. & 578 & 57.8 & 67.6 \\
\hline & Magazines & 1 & .1 & .1 \\
\hline & News paper & 65 & 6.5 & 7.6 \\
\hline & Online & 60 & 6.0 & 7.0 \\
\hline & Friends & 151 & 15.1 & 17.7 \\
\hline & Total & 855 & 85.5 & 100.0 \\
\hline Missing & System & 145 & 14.5 & \\
\hline \multicolumn{2}{|l|}{ Total } & 1000 & 100.0 & \\
\hline
\end{tabular}

It is clearly shows that 578 or $67.6 \%$ respondents or buyers firstly knew about Patanjali from TV, 1 or .1\% from Magazines, 65 or $7.6 \%$ from Newspaper, 60 or $7 \%$ from Online, 151 or $17.7 \%$ from friends. It is important to see that there is a difference between Percent and valid percent because of Missing frequency or Non-buyers.

4.2.1).3) Different kind of products, they have used: The researcher has used a question that 'what kind of products they have used'? Table 4.9 shows the frequency and percentages of different products that have been used by buyers. 
International Journal of Trend in Scientific Research and Development (IJTSRD) ISSN: 2456-6470

\begin{tabular}{|c|c|c|c|c|}
\hline \multicolumn{5}{|c|}{\begin{tabular}{|l|} 
TABLE 4.9 \\
Kind of Products used by buyers \\
\end{tabular}} \\
\hline \multicolumn{2}{|c|}{ Category } & Frequency & Percent & Valid Percent \\
\hline & Skin care & 278 & 27.8 & 32.5 \\
\hline & Health and personal care & 168 & 16.8 & 19.6 \\
\hline & Food and grocery & 66 & 6.6 & 7.7 \\
\hline & Medicines & 122 & 12.2 & 14.3 \\
\hline & Others (khad, zinc, etc.) & 7 & .7 & .8 \\
\hline & Skin and health & 38 & 3.8 & 4.4 \\
\hline & Skin and food and grocery & 20 & 2.0 & 2.3 \\
\hline & Skin and medicines & 72 & 7.2 & 8.4 \\
\hline & Skin and others & 5 & .5 & .6 \\
\hline & Health and food and grocery & 19 & 1.9 & 2.2 \\
\hline & Health and medicines & 19 & 1.9 & 2.2 \\
\hline & Food and herbal medicines & 3 & .3 & .4 \\
\hline & Skin, health, food, medicines. & 12 & 1.2 & 1.4 \\
\hline & All types & 26 & 2.6 & 3.0 \\
\hline & Total & 855 & 85.5 & 100.0 \\
\hline Missing & System & 145 & 14.5 & \\
\hline \multicolumn{2}{|l|}{ Total } & 1000 & 100.0 & \\
\hline
\end{tabular}

It is clearly shown in the table that 278 or $32.5 \%$ buyers used skin care products, 168 or $19.6 \%$ used health and personal care products, 66 or $7.7 \%$ used food and grocery products, 122 or $14.3 \%$ used medicines, 7 or $7.7 \%$ used other products like khad ,zinc, 38 or $4.4 \%$ used both skin and health care products, 20 or $2.3 \%$ used skin and food \&grocery products, 72 or $8.4 \%$ used skin and medicines, 5 or $.6 \%$ used skin and others products like khad,zinc,etc., 19 or $2.2 \%$ used health and food \&grocery products, 19 or $2.2 \%$ used health and medicines, 3 or $.4 \%$ used food and medicines, 12 or $1.4 \%$ used skin, health, food, and medicines, 26 or $3 \%$ used all type of products.
Interpretations: As the above table shows majority of respondents are using skincare products, after that health \& personal care products, and after that medicines. The remaining products are least preferred by the respondents.

4.2.1).4 Quality of Patanjali products: For this purpose researcher has used a question that 'How will they rate the performance of Patanjali products'? Table 4.10 shows rating quality of Patanjali products given by buyers of Patanjali products.

TABLE 4.10
Quality of Patanjali products
\begin{tabular}{|l|l|l|l|l|l|} 
Category & Frequency & Percent & Valid Percent & \\
\hline \multirow{8}{*}{} & Excellent & 225 & 22.5 & 26.3 & Cumulative Percent \\
\cline { 2 - 6 } & Very good & 215 & 21.5 & 25.1 & 26.3 \\
\cline { 2 - 6 } & Good & 335 & 33.5 & 39.2 & 51.5 \\
\cline { 2 - 6 } & Satisfactory & 79 & 7.9 & 9.2 & 90.6 \\
\cline { 2 - 6 } & Poor & 1 & .1 & .1 & 99.9 \\
\cline { 2 - 6 } & Total & 855 & 85.5 & 100.0 & \\
\hline Missing & System & 145 & 14.5 & & 100 \\
\hline Total & 1000 & 100.0 & & \\
\hline
\end{tabular}

It is shown in the table that 225 or $26.3 \%$ respondents said excellent quality of Patanjali products, 215 or $25.1 \%$ said very good, 335 or $39.2 \%$ said good, 79 or $9.2 \%$ said satisfactory, 1 or .1\% said poor quality of Patanjali products. 
International Journal of Trend in Scientific Research and Development (IJTSRD) ISSN: 2456-6470

4.2.2) Consumers attitude towards the elements of the 'Patanjali' retail products: Attitude consists of thoughts or beliefs, feelings and intentions towards a particular product or services. Understanding consumer's attitude can help a marketer understand consumers better and even change their attitudes. Table 4.11 shows attitude of buyers toward s elements of Patanjali products. In this table researcher has used six elements of Patanjali products and researcher has analyzed these elements through drawing frequencies, percentages and cumulative percentages and after that given them rank. Five Likert scale was used to measure the consumer response.

\begin{tabular}{|c|c|c|c|c|c|c|}
\hline \multicolumn{7}{|c|}{$\begin{array}{l}\text { Attitude toward s the elements of 'Patanjali' products(Frequency, valid percentage, cumulative } \\
\text { percentage) }\end{array}$} \\
\hline Elements/Rate & $\begin{array}{l}\text { Very bad } \\
\text { F/VP/CP }\end{array}$ & $\begin{array}{l}\mathrm{Bad} \\
\mathrm{F} / \mathrm{VP} / \mathrm{CP}\end{array}$ & $\begin{array}{l}\text { Average } \\
\mathrm{F} / \mathrm{VP} / \mathrm{CP}\end{array}$ & $\begin{array}{l}\text { Good } \\
\text { F/VP/CP }\end{array}$ & $\begin{array}{l}\text { Very good } \\
\text { F/VP/CP }\end{array}$ & Rank \\
\hline Price & $0 / 0 / 0$ & $20 / 2.3 / 100$ & $393 / 46 / 97.7$ & $263 / 30.8 / 51.7$ & $179 / 20.9 / 20.9$ & 6 \\
\hline Quality & $0 / 0 / 0$ & $0 / 0 / 0$ & $173 / 20.2 / 100$ & $327 / 38.2 / 79.8$ & $355 / 41.5 / 41.5$ & 1 \\
\hline Packaging & $0 / 0 / 0$ & $0 / 0 / 0$ & $218 / 25.5 / 100$ & $402 / 47 / 74.5$ & $235 / 27.5 / 27.5$ & 3 \\
\hline Quantity & $0 / 0 / 0$ & $0 / 0 / 0$ & $254 / 29.7 / 100$ & $382 / 44.7 / 70.3$ & $219 / 25.6 / 25.6$ & 5 \\
\hline Availability & $0 / 0 / 0$ & $0 / 0 / 0$ & $226 / 26.4 / 100$ & $328 / 38.4 / 73.6$ & $301 / 35.2 / 35.2$ & 4 \\
\hline Advertisements & $0 / 0 / 0$ & $1 / 0.1 / 100$ & $190 / 22.2 / 99.9$ & $254 / 29.7 / 77.7$ & $410 / 48 / 48$ & 2 \\
\hline
\end{tabular}

As the above table indicates out of 1000 respondents, 393 or $46 \%$ respondents have average, 20 or $2.3 \%$ have negative, 263 or $51.7 \%$ have good, and 179 or $20.9 \%$ have very good attitude regarding price. 173 or $20.2 \%$ respondents have average, 327 or $38.2 \%$ have well, and 355 or $41.5 \%$ have very good attitude regarding quality. 218 or $25.5 \%$ respondents have average, 402 or $47 \%$ have well, and 235 or $27.5 \%$ have very good attitude regarding packaging. 254 or $29.7 \%$ respondents have average, 382 or $44.7 \%$ have well, and 219 or $25.6 \%$ have very good attitude regarding quantity. 226 or $26.4 \%$ respondents have average, 328 or $38.4 \%$ have well, and 301 or $35.2 \%$ have very good attitude regarding availability. 1 or $.1 \%$ respondents have bad, 190 or $22.2 \%$ have average, 254 or $29.7 \%$ have well, and 410 or $48 \%$ respondents have very good attitude regarding advertisements.

4.2.3) Consumers preferences towards the Patanjali retail products: Consumer preferences are defined as the individual tastes, as measured by the levels of utility that a product or services give to the consumer. Table 4.12 shows the preference towards the 'Patanjali' products.

\section{TABLE 4.12}

Preferences towards the elements of 'Patanjali' products(Frequency, percentage,cumulative percentage)

\begin{tabular}{|l|l|l|l|l|l|c|}
\hline Elements/Rate & $\begin{array}{l}\text { Strongly disagree } \\
\text { F/VP/CP }\end{array}$ & $\begin{array}{l}\text { Disagree } \\
\text { F/VP/CP }\end{array}$ & $\begin{array}{l}\text { Neutral } \\
\text { F/VP/CP }\end{array}$ & $\begin{array}{l}\text { Agree } \\
\text { F/VP/CP }\end{array}$ & $\begin{array}{l}\text { Strongly agree } \\
\text { F/VP/CP }\end{array}$ & Rank \\
\hline Reasonable Price & $0 / 0 / 0$ & $42 / 4.9 / 100$ & $309 / 36.1 / 95.1$ & $309 / 36.1 / 58.9$ & $195 / 22.8 / 22.8$ & 7 \\
\hline Better Quality & $0 / 0 / 0$ & $22 / 2.6 / 100$ & $272 / 31.8 / 97.4$ & $268 / 31.3 / 65.6$ & $293 / 34.3 / 34.3$ & 2 \\
\hline Swadeshi & $38 / 4.4 / 100$ & $1 / 1.1 / 95.6$ & $290 / 33.9 / 95.4$ & $243 / 28.4 / 61.5$ & $283 / 33.1 / 33.1$ & 5 \\
\hline Herbal products & $0 / 0 / 0$ & $21 / 2.5 / 100$ & $290 / 33.9 / 95.4$ & $268 / 31.3 / 63.6$ & $276 / 32.3 / 32.3$ & 4 \\
\hline Easy availability & $0 / 0 / 0$ & $0 / 0 / 0$ & $309 / 36.1 / 100$ & $209 / 24.4 / 63.9$ & $337 / 39.4 / 39.4$ & 3 \\
\hline $\begin{array}{l}\text { Attractive } \\
\text { packaging }\end{array}$ & $0 / 0 / 0$ & $20 / 2.3 / 100$ & $313 / 36.6 / 97.7$ & $342 / 40 / 61.1$ & $180 / 21.1 / 21.1$ & 6 \\
\hline Baba Ramdev & $0 / 0 / 0$ & $0 / 0 / 0$ & $270 / 31.6 / 100$ & $353 / 41.3 / 68.4$ & $232 / 27.1 / 27.1$ & 1 \\
\hline
\end{tabular}

As the table indicates that in cumulative percentage $58.9 \%$ respondents prefer Patanjali products due to reasonable price, $65.6 \%$ respondents prefer due to better quality, $61.5 \%$ prefer due to Swadeshi, $63.6 \%$ due to herbal products, $63.9 \%$ due to easy availability, $61.1 \%$ due to attractive packaging, and $68.4 \%$ respondents prefer due to Baba Ramdev. 


\section{CONCLUSIONS:}

As the above analyses indicate that majority of respondents aware and have used 'Patanjali' retail products as well as they show positive attitude regarding 'Patanjali' products. Also T.V.is the important source of 'Patanjali' products. Mostly buyers prefer these products due to better quality and due to Baba Ramdev. Majority of buyers think that they are easy available, but the weakest elements is price. That's not mean, price of Patanjali products are higher than other competitive brands but price is unattractive so suitable action should be done in respect to price of Patanjali products.

\section{Managerial Implications:}

This analysis will help the marketers for knowing about 'Patanjali' product's strength, weaknesses, awareness, attitude and preference regarding elements of 'Patanjali' retail products, so that necessary plans and strategies can be formulate and as well as implement.

\section{REFERENCES:}

1. Kumar, Ajeet and Anshu Ahuja (2017), "Consumer behaviour towards Patanjali products: A study on consumers with reference to Rohtak district of Haryana", Vol-4, Issue-2.

2. Gosher, Seema (2017), "Customer preferences towards Patanjali products: A study on consumers with reference to Mumbai Suburban district", IJARIIE, Vol-3, Issue-1.

3. Somvanshi, Kiran Kabtta (2016), "Patanjali's success may lead to a FMCG rejig", ET Bureau.

4. Anand, Shambhavi and Ratna Bhushan (2016), "Baba Ramdev alleges adulteration of Patanjali products by FMCG companies", ET Bureau.

5. Ghosal, Sutanuka (2016), "Solvent extractors to approach food, advertising regulators against Patanjali advertisement", ET Bureau.

6. Somvanshi, Kiran Kabtta (2016), "Six lessons that Patanjali teaches India's FMCG sector", ET Bureau.

7. Vyas, Jwalit (2016), "After Patanjali, existing FMCG players may face challenge from Sri Sri Ravi Shankar's Sri...", ET Bureau.

8. Dehghan, Ali (2011), "Customer Loyalty Assessment: A case study in MADDIRAN, the Distributor of LG Electronics in Iran" Business Management and Strategy, Vol.-2. 